\title{
THE SETO MARINE BIOLOGICAL LABORATORY OF KYOTO UNIVERSITY
}

$\operatorname{AUTHOR(S):~}$

Miyadi, Denzaburo; Utinomi, Huzio

\section{CITATION:}

Miyadi, Denzaburo ... [et al]. THE SETO MARINE BIOLOGICAL LABORATORY OF KYOTO UNIVERSITY. PUBLICATIONS OF THE SETO MARINE BIOLOGICAL LABORATORY 1952, 2(2): 41-52

ISSUE DATE:

1952-10-05

URL:

http://hdl.handle.net/2433/174688

RIGHT: 


\title{
THE SETO MARINE BIOLOGICAL LABORATORY OF KYOTO UNIVERSITY*
}

\author{
DENZABURo MIYADI (Director) \\ and \\ Huzio UTINOMI (Superintendent)
}

With Plates II-V

\section{HISTORICAL SKETCH}

1922 Laboratory established at the village of Seto-kanayama (Sirahama Town now named), Wakayama Prefecture. Whole buildings completed in spring and actual activities began in summer (July 28) under the directorship of Prof. T. Kawamura.

1923 Prof. T. KomaI elected Administrator of the Laboratory.

1929 His Majesty the Emperor visited the Laboratory on the way of his journey to Kansai districts.

Aquarium attached to the Laboratory began to open to the public and then enlarged.

1934 Prof. Yo K. OKADA elected Administrator of the Laboratory.

1935 Research ship the "Nyîsin-maru" sold and a new motor boat the "Pelagia" arrived.

1937 Prof. T. Koma. elected again Administrator of the Laboratory the name of which was henceforth altered to Director by the reform of government organization.

1944 Amargamation of the Memorial Museum of Natural History at Setokanayama with the Laboratory. The former was rebuilt after removal to the site of the Laboratory.

1946 Prof. D. MIYADI elected Director of the Laboratory.

Many of laboratory buildings and their equipments damaged by great earthquake shock on December 21th.

* Contributions from the Seto Marine Biological Laboratory, No. 175.

Publ. Seto Mar. Biol. Lab., II (2), 1952.. (Article 3) 
1948 Research laboratory and aquarium buildings rebuilt. 1951 Students' laboratory renovated.

\section{STAFF}

\section{Present Personnet}

\section{Scientific Staff}

Director (Part-time): Frof. Denzaburo MiYadi, M.Sc., D.Sc., M.J.S.C. (Ecologist) Superintendent: Huzio UTINomi, M. Sc., D. Sc. (Zoologist)

Scientific Officers: Takasi ToxlokA, M.Sc., D.Sc. (Zoologist and planktologist) Isamu YaMAZI, M. Sc. (Hydrologist and planktologist)

(Non-resident) Tokubei Kuroda, D. Sc. (Nalacologist)

(Part-time) Tadashige HA3E, M.Sc. (Malacologist and ecologisi)

\section{Laboratory Staff}

Skipper and Collector (Temporary): Yanosuke SAJAIL.

Engine er and Collector: Syûzi URA and Syôzô SAKAI.

Laboratory assistant (Part-time): Torao YAMAMoro.

Typist and Clerical assistant: Miss Yoshiko Mori.

Janitor and Cook: Toyomatu TuzI.

Housekeeper: Mrs. Kilue Tuzi.

Other 3 temporarily appointed aquarium attendants.

\section{Former Personnel}

Director

Tamiji Kawamura, Prof., M. Sc. (Rector of Pref. University of Siga, Hikone) 1922-23

Taku Komai, Frof., D. Sc., M.J.A. (Chief member of National Insizitute of

Genetics, Misima)

1923-33, 1937-46

Yô K. OzadA, Prof., M.Sc., D. Sc., M.J.A. (Formerly Dean of Science

Faculty, Tokyo University, Tokyo)

$1933-37$

\section{Seientific Staff}

Jiro IKARI* (Deceased in July 1937)

Kôzô Azatsuxa (Lecturer of Prefectural University of Mie, Tu)

Iwao TAKi, M. Sc., D. Sc. (Professor of Hirosima University, Mukaizima) 1928-31 
Hisao Sugino, M. Sc. (Professor of Osaka University of Liberal Arts, Osaka) 1931 Sueo M. Shiino, M. Sc., D. Sc. (Professor of Prefectural University of Mie, Tu)

Yoshinobu MiYashita** M. Sc. (Deceased in July 1942)

$1932-35$

Yasuhiro Tokuoka (Researcher of Nihon Yusi K.K. Research Insiitute, Kawasaki)

1934-38

Kiyoshi Hirabayashi, M.Sc., D.E. (Ass'ni professor of lnstilute of Chemical

Research, Kyoio University, Takaiuki)

$1934-38$

Denzaburo MiYadi, M. Sc., D. Sc. (Professor of Kyoto University, Kyoto) 1936-42

Kanefumi Nozawa, M. Sc, D. Sc. (Dececsed in February 1946) 1939-41, 1942-46

Tetsuo Masui* (Deceased in October 1942)

$1940-42$

Sôichirô SAKAgUchi (Wakayama)

$1942-46$

Nobuyuli TAKEDA, M.Sc, D. Sc. (Formerly Professor of Prep. Department of Syowa Medical College, Tokyo) $1942,1944-47$

Miss Chiyoko Kasuya (Mrs. N. Takeda)

$1943-47$

Yoshichi MATSUI, D. Ag. (Director of Nippon Institute for Scientijic Resectrch on Pearl, Kyoto)

$1946-48$

Miss Miho Irari (Teacher of Hatiman High School, Hatiman)

$1947-50$

* Deceased

\section{LOCATION}

The Laboratory is located on a little peninsula on the west coast of Kii Province, about 40 miles northwest of Siono-misaki, the southernmost promontory of the main island of Japan and about 80 miles south of Osaka. The site is formerly named Seto-kanayama as village and now Sirahama Town since 1940. The town is well known as a hot-spring place with beautiful landscape and natural monuments, and many tourists at home and abroad visit for sight-seeing and taking a bath.

In addition, the marine life in the environs, littoral as well as pelagic, is characterized by its tropical faces and also by the richness and diversity in forms. This is due to the influence of a northerly branch of the "Kurosio" current washing along the west coast of Kii Peninsula, and also to the profuse indentations of the sea floor. The location of the Laboratory furnishes naturalists with excellent working grounds and is thus available as a base for wide-range field work involving both the terrestrial and marine biology in southern Honsyu.

During the thirty years since its establishment, various improvements have been made, and the Laboratory is now becoming one of the centers for the promotion of marine science in Japan. 


\section{EQUIPMENT AND FACILITIES}

The area belonging to the Laboratory covers about 33,680 sq. m. on the tombolo hemmed in between the sea on the north and south. The Laboratory as a whole consists of ten separate buildings. They are all flat wooden houses, except only the museum being of two-stored.

$\begin{array}{lll}\text { Research laboratory } & 1 & \text { (303 sq.m.) } \\ \text { Special research laboratory } & 1 & (168 \text { sq.m.) } \\ \text { Students' laboratory } & 1 & (224 \text { sq.m. }) \\ \text { Aquarium } & 1 & (407 \text { sq.m. }) \\ \text { Museum } & 1 & (218+204 \text { sq. m. }) \\ \text { Dormitories } & 2 & (302 \text { sq.m., } 173 \text { sq.m. }) \\ \text { Official residences } & 3 & (221 \text { sq.m. })\end{array}$

The main laboratory contains twelve rooms of concrete floor: an office, library, instrument-working room, storage room, photographic dark room, physiological room, chemical room, oceanographical room and three individual research rooms, seven of which are supplied with running fresh and salt water fittings, and a wide cement sink, and also with electric light and power (3phase, $110 / 220$ volts, 60 cycle). Equipments for general biological and hydrological researches are mostly available. For collecting material and work on the sea there are at present two vessels, one called the "Janthina II" of 3 tons capacity, equipped with a 7.5 h.p. Diesel gas engine and a row boat called the "Obelia".

Besides these, the Laboratory has now been equipped with improved facilities for regular meteorological observations.

The Laboratory was established primarily to provide facilities for research in marine biology and also to give students in that university laboratory courses in marine biology. Since the war, however, the Laboratory has been opened for a course in marine biology and elementary oceanography to undergraduate students in other universities or colleges and to teachers of biology in public schools of lower grade, mainly from April to August. During the spring and summer vacations of every year, the Laboratory is crowded with many enthusiastic students.

The course is regularly conducted by members of the laboratory staff and by teachers of other schools attended. Usually it consists of lectures, laboratory excercises, field works, collecting trips and discussions. During the course some pamphlets for guide to excercises printed by the Laboratory are freely used. Since the war, students and teachers attended to these courses have successively been increased year after year, as follows. 


$\begin{array}{cccc}\begin{array}{c}\text { Schools } \\ \text { or parties }\end{array} & \text { Days } & \text { Attendants } \\ 1946 & 6 & 20 & 72 \\ 1947 & 8 & 36 & 103 \\ 1948 & 18 & 67 & 196 \\ 1949 & 19 & 80 & 397 \\ 1950 & 13 & 62 & 312 \\ 1951 & 23 & 90 & 370\end{array}$

Besides, the following is the number of visitors working at the Laboratory in recent years since the war.

\begin{tabular}{ll|ll}
1946 & 14 & 1949 & 17 \\
1947 & 15 & 1950 & 25 \\
1948 & 14 & 1951 & 36
\end{tabular}

Research work by members of the laboratory staff has been proceeding actively. In other respects also the Laboratory offers special facilities for instruction in marine science, and thus promotes for the advancement of marine research in our country.

\section{IIBRARY}

The Library contains many of the important marine biological journals, several thousand reprints and about 2000 bound volumes. The reports of expeditions, monographs and other books not found in the Library have temporarily been borrowed from the Zoological Institute of Kyoto University at Kyoto. The recent valuable additions to the Library include a complete set of algological and planktological books and reprints belonging to the late Jiro IKARI, one of the founders of the Laboratory. The Library has lately been much used by visiting workers or students in other universities.

The number of periodicals or reprints of papers being regularly received by the Library has been appreciably increased during recent years by gifts or exchanges. Thanks of the Laboratory are due to many Departments or Institutions at home and abroad for their gifts and courtesies presented to the Library. The following is a list of the periodicals and publications received since the end of War II. Subtitles of journals and reports in Japanese are given in the original form as well as in explanatory English translation if no accepted translation could be found.

\section{Australia}

Australian Jour. Mar. and Freshw. Research, Melbourne. Bulletin C.S.I.R.O., Melbourne. 
Memoirs Queensland Museum, Brisbane.

Technical Paper C.S.I.R.O., Melbourne.

\section{BEI.GIUM}

Bull. Inst. Royal Sci. Nat. Belgique, Bruxelles.

Inst. Zool. Ed. Van Beneden, Liège. (Travaux)

\section{BERMUDA}

Bermuda Biol. Siat. Res., Bermuda. (Contributions)

\section{CANADA}

Annual Report, Fish. Board of Canada, Ottawa. Bull. Fish. Res. Board of Canada, Ottawa. Jour. Fish. Res. Board of Canada, Ottawa. Rapport Annuel, Stat. Biol. St-Laurent, Québec. Stat. Biol. St-Laurant, Québec. (Contributions)

\section{CEYLON}

Fish. Res. Station, Colombo. (Reprints)

\section{China}

Amoy Fisheries Bulletiz, Amoy.

\section{DENMARIS}

Report Danish Biol Stat., Charlottenlund.

\section{EGYPI}

Publications Mar. Biol. Slat., Gardaqa.

\section{Finiand}

Amales Bot. Soc. Fennicae "Vanamo", Helsinki. Amales Zool. Soc. Fennicae "Vanamo", Helsinki. Archivum Soc. Zool. Bot. Fennica" Vanamo", Helsinki. Zool. Station, Tvärminne. (Contributions)

\section{FRANCE}

Bull. Inst. Océanogr., Monaco.

Bull. Lab. Marit., Dinard.

Bull. Mus. Nation. Fist. Nat., Paris.

Bull. Stat. Biol., Arcachon.

Stat. Biol., Roscoff. (Travaux et ses Supplément)

Stat. Mar. Endoume, Marseille. (Travaux)

Siat. Zool., Villefranche-sur-Mer. (Travaux)

Unesco Bulletin for Libraries, Paris.

Vie et Milieu/Bull. Lab. Arago, Banyuls-sur-Mer.

\section{FRENCH WEST AFrICA}

Bull. Inst. Français d'Afrique Noire, Dakar.

Bull. Soc. Sci. Nat. Maroc, Rabat. 
Comptes Rendus Séances Mens., Séance Hydrogéol., Rabat.

Intiations Africaines, Dakar.

Mém. Inst. Français d'Afrique Noire, Dakar.

Mém. Soc. Sci. Nat. Maroc., Rabat.

Travaux Inst. Sci. Cherifien, Rabat.

\section{GermanY}

Helgoländer Wissenschaftiche Meeresuniersuchungen, List auf Sylt.

Kieler Meeresforschungen, Kiel.

Kurze Mitteilungen Fischereibiol. Abt, Max Planck-Inst. Meeresbiol., Wilhelmshaven.

Senckenberg am Meer, Wilhelmshaven.

Veröffentlichungen Inst. Meeresforschung, Bremerhaven.

\section{Great Britain}

Annual Report Scottish Marine Biol. Assoc, Millport.

Bibliographical Series, Science Library, London.

Dept. Zool., Univ. Coll., Hull. (Reprints)

Dept. Zool., Univ. of Cambridge, Cambridge. (Reprints)

Dept. Zool., Univ. of Edinburgh, Edinburgh. (Reprints)

Dept. Zool., Univ. of Manchesier., Manchester. (Reprints)

Fishery Invesigations, Min. Agr. \& Fish., Series I \& II, London.

Hull Bulletins of Marine Ecology, Hull.

Jour. Mar. Biol. Assoc. United Kingdom, Plymouth.

Report, Dove Marine Lab., Cullercoasts, Newcastle.

Report on Fisheries of Scotland, Scottish Home Dept., Edinburgh.

Sci. Invest., Scottish Hlome Dept., Edinburgh.

Scottish Mar. Biol. Assoc., Millport. (Collected Reprints)

Scottish Sea Fisheries Siatistical Tables, Scottish Home Dept., Edinburgh.

Statisical Tables, Sea Fisheries, Min. Agr. \& Fish., London.

\section{Holtand}

Amsterdam Naturalist, Amsterdam.

Beaufortia, Zoül. Mus., Amsterdam.

Zoologische Mededelingen, Leiden.

Zoologische Verhandelingen, Leiden.

INDIA

Bull. Madras Government Mus., Nat. Hist. Section, Madras.

Freshwater Biol. Stat. Madras Fisheries, Madras. (Reprints)

Records Indian Mus./Jour. Ind. Zool., Calcutta.

INDOCHINA

Inst. Oceanogr. Indochine, Nhatrang. (Contributions)

Mém. Inst. Océanogr. Indochine, Nhatrang.

Notes Inst. Océanogr. Indochine, Nhatrang.

INDONESIA

Treubia, Bogor. 
ITALY

Bibliographia Océanographica, Roma-Venezia. Bollettino Pesca Piscicolt. Iarobiol., Roma.

Nova Thalassia, Venezia.

Pubbl. Ist. Zool. Anat. Comp., Padova. (Collected Reprints)

Pubbl. Staz. Zool., Naples.

\section{JAPAN}

Akkeshi Mar. Biol. Stat., Hokkaido Univ., Akkesi. (Contributions)

'Animals and Zoo' (Е゙5 ぶつと動物園), Tokyo.

Annual Report Central Fish. Exper. Stat. (水䓛試驗場年報), Tokyo.

Annual Report National Inst. Genetics (國立遺傳學研究所年報), Misima.

Biol. Jour. Okayama Univ., Okayama.

Bull. Biogeogr. Soc. Japan (日本生物地理學會及報), Tokyo.

Bull. Fac. Fish. Hokkaido Univ. (北海道大學水產學部研究笨報), Hakodate.

Bull. Fish. Exper. Stat. Hyogo-Ken (兵庫鲧水產試驗場試驗報告), Akasi.

Bull. Inst. Chem. Res. Kyoto Univ. (京都大學化學研究所報告), Takatuki.

Bull. Japan Sea Regional Fish. Res. Lab. (日本海區水產研究所研究報告), Nanao.

Bull. Kobe Marine Observatory (神戸海洋氣像台黄報), Kobe.

Bull. Maizuru Marine Observatory (舞鹤海洋釆像台要報), Maizuru.

Bull. Mar. Biol. Stat. (海洋生物時報), Asamusi.

Bull. Nagasaki Marine Observatory (長崎海洋特報), Nagasaki.

Bull. National (or Tokyo) Science Museum (國立科學博物館研究報告), Tokyo.

Bull. Tokai Regional Fish. Res. Lab. (東海區水產所究所研觉報告), Tokyo.

Bull. Tokyo Inst. Technology, Ser. $A$ \& B, Tokyo.

'Business Rep. Fish. Res. Lab.' (水重研究所事業報告), Fish. Agency, Tokyo.

Central Fish. Exper. Stat., Tokyo. (Contributions)

Ecological Review (生態學研焒), Sendai.

Fish. Lab. Fac. Agr., Tokyo Univ., Sinmaiko-Ikawazu. (Contributions)

Fisheries Statistical Bulletin (水產統計資料), Fish. Agency. Tokyo.

Icones Marine Animals \& Plants in Hokkaido (北海道海烧動植物圖譜), Yoiti.

Illust. Catalogue of Japanese Shells (日本貝類圖錄), Kyoto.

Jap. Jour. Ichthyology (魚類學䆶誌), Tokyo.

Jour. Dept. Agr. Kyushu Univ., Hukuoka.

Jour. Fac. Fish. Pref. Univ. of Mie (三重縣立大學水產學部紀要)， Tu.

Jour Fisheries (水產學雜誌), Hakodate.

Jour. Fish. Res. Inst. (水產研究會報), Tokyo.

Jour. Hokkaido Fish. Exper. Stat. (北水呞月報), Yoiti.

Jour. Inst. Polytechnics, Osaka City Univ., Ser. D. Biol., Osaka.

Jour. Inst. Res. Sci. Fish., Hakodate Coll. Fish. (水產科學研先所報告), Hakodate.

Jour. Kagoshima Fish. Coll.（鹿兒島水產專問學校研究報告)，Kagosima.

Jour. Oceanogr. Soc. Japan. (日本海洋學會誌), Tokyo.

Jour. Oceanogr., Kobe Mar. Observ, (神戸海洋時報), Kobe.

Jour. Oceanogr., Maizuru Mar. Observ. (舞鹤海洋㭙報), Maizuru.

Jour. Sci. Hirosima Univ., Ser. B, Divs. 1 \& 2, Hirosima.

Jour. Shimonoseki Coll. Fish. (第二水產講習所研究報告), Simonoseki.

Jour. Tokyo Univ. Fish. (東京水産大學研究報告), Yokosaka. 
Jour. Wakayama Fish. Sci. Inst. (和歌山眯水產試驗場事業月報), Tanabe.

Mem. Coll. Agr. Kyoto Univ., Fisheries Series, Kyoto.

Mem. Coll. Sci. Univ. Kyoto, Ser. $A$ \& B. Kyoto.

Mem. Kobe Mar. Observ., Kobe.

Misc. Rep National Sci. Mus. (國立科學博物館集報)，Tokyo.

Misc. Rep. Res. Inst. Nat. Res. (資源科學研究所暳報)，Tokyo.

Museum Studies (博物館研究), Tokyo.

'Monthly Rep. Ocennogr. Cond. Japan Sea' (裹日本海況月報), Maizuru.

Nanki Seibutsu and its Supplement (南紀生物), Sirahama.

Natural Science and Museums (自然科學上博物館), Tokyo.

Oceanographical Chart (海洋圖), Tokyo.

Oceanographical Data (海況速報), Maizuru.

Oceanographical Reports (海洋報告一海洋時報), Maizuru.

Oceanography and Meteorology (海鱼之氣象), Nagasaki.

Physiology and Ecology (生理生態), Kyoto.

Proc. Japan Acad., Tokyo.

Publ. Akkeshi Mar. Biol. Stat.; Akkesi.

Reports and Preliminary Study, Natural Resources Section, SCAP, Tokyo.

Rep. Inland Sea Fish. Co-operative Invest., Naikai Regional Fish. Res. Lab. (瀨F 内海水座連絡語查要報), Hiroshima.

Rep. Inst. Agr. Res., Tohoku Univ., Sendai.

Rep. Fac. Fish. Pref. Univ. of Mie, Tu.

'Rep Jap. Assoc. Museums' (日本博物館溜會及報), Tokyo.

Rep. Köchi Univ., Nat. Sci. (高知大學研究䠟告), Kôchi.

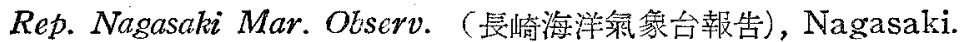

'Rep. Physiol. \& Ecol., Coll. Sci., Kyoto. Univ.' （宗都大學理學部生理生態學研究業 績), Kyoto.

Rep. Plankton (浮游生物速報), Mar. Observ., Kobe.

'Res. Rep. Benthic Fish Resources' (底魚盗源調查要報), Tokyo-Nanao.

'Res. Rep. Productivity of Inland Sea' (生產力澗査要報), Tokyo.

'Res. Rep. Resources of Skipjacks and Tunas' (カツオ, マグロ資源調查嚣報), Tokyo.

Science of the Sea (海洋の科學), Tokyo.

Sci. Bull. Pac. Agr. Kyushu Univ.（九州大要農學部學蔡雜誌), Hukuoka.

Sci. Pap. Hokkaido Fish. Sci. Inst. (北海道區水窐研究所研究報告), Yoiti.

Sci. Pap. Inst. Algolog. Res., Hokkaido Univ., Muroran.

Sci. Rep. Saitama Univ., Ser. B, Urawa.

Sci. Rep. Tohoku Univ., Fourth Ser. (Biol.), Sendai.

Semi-annual Rep. Oceanogr. Invest. (海洋調查要報), Tokyo.

Shimoda Mar. Biol. Stat., Tokyo Bunrika Daigaku, Simoda. (Contributions)

Tohoku Jour. Agr. Res., Tohoku Univ., Sendai.

Venus/Jap. Jour. Malac. (ヴキナス:貝類學放誌), Mukaisima.

JugosLAVIA

Acta Adriatica, Split.

Notes Inst. Ocean. Ribarstvo, Split.

Rep. Inst. Ocean. Ribarstvo, Split. 
New Zealand

Bulletin Auckland Inst. and Mus., Auckland. Records Auckland Inst. and Mus., Auckland.

Report on Fisheries, Marine Department, Wellington.

\section{NORWAY}

Fiskeridirektoratets Skrifter, Ser. Havundersökelser, Bergen.

Hvalradets Skrifter, Oslo.

Tromsö Musems Arshefier, Tromsö.

Univ. i Bergen Arbok, Naturvitenskapelig Rekke, Bergen.

Univ. $i$ Bergen Årberetning, Bergen.

Portugal

Travanx Stat. Biol. Maritime, Lisboa.

\section{South Africa}

Annual Report, Division of Fisheries, Sea Point.

Investigational Report, Fish. Mar. Biol. Surv. Div., Sea Point.

\section{SpaIN}

Boleìn Inst. Español Oceanografia, Madrid.

Trabajos, Inst. Español Oceanografia, Madrid.

\section{SWEDEN}

Arkiv for Zoologi, Stockholm.

Further Zool. Res. Swed. Antarctic Exped., Stockholm.

Kungl. Svenska Vetensk. Akad. Handlingar, Stockholm.

Meddelanden Oceanografiska Institutet, Göteborg.

Undersökningar över Öresund, Lund.

Zoologiska Institutionen, Lund. (Contributions)

Thamand

F. A. O. Current Affairs Bulletin, Bangkok.

Proc. Indo-Pacific Fisheries Council, Bangkok.

Tunisia

Bulletin Stat. Océanogr., Salammbô.

TURKEY

Publ. Hydrobiol. Res. Inst., Fac. Sci., Univ. of Isianbul. Ser. E, Istanbul.

\section{U. S. A.}

Allan Hancock Pacific Expeditions, Los Angeles.

American Museum Novitates, New York.

Annual Rep., Chicago Nat. Hist. Mus., Chicago.

Annual Rep., Mount Desert Islands Mar. Biol. Lab., Salisbury Cove.

Annual Rep., Mus, Comp. Zoöl. Harvard Univ., Cambridge. 
Bull. Amer. Mus. Nat. Hist.. New York. (Marine biology)

Bull. Bernice P. Bishop Mus., Honolulu. (Zoology and Entomology)

Bull. Bingham Oceanogr. Coll., New Haven.

Bull. Duke Univ. Mar. Station, Beaufort.

Bull. Mus. Comp. Zö̈l. Harvard Univ., Cambridge. (Marine zoology)

Bull. Scripps. Inst. Oceanogr., La Jolla.

Bull. U. S. Nat. Mus., Washington.

California Fish and Game, San Francisco.

Duke Univ. Mar. Stat., Beaufort.(Contributions, Ser. A)

Educational and Technical Series, Florida State Board of Conserv., Coral Gables, Florida.

Fieldiana-Zoology, Chicago Nat. Hist. Mus., Chicago. (Ichthyological papers).

Fish Bulletin, Division of Fish and Game, San Francisco.

Fishery Bulletis, U. S. Fish and Wildlife Service, Washington.

Fisheries Statistics of the United Siates, U.S. Fish and Wildlife Service, Washington.

Hopkins Marine Station, Pacific Grove. (Reprints)

Jour. Entom. Zool., Claremont.

Mem. Bernice P. Bishop Mus., Honolulu.

Mimeographed Rep., Univ. of Miami Marine Lab., Coral Gables.

Occasional Papers, Bernice P. Bishop Mius., Honolulu. (Zoology and Entomology)

Pacific Science, Honolulu.

Proc. Gulf and Caribbean Fish. Inst., Coral Gables.

Proc. U. S. Nat. Mus., Washington. (Marine zoology)

Publ. Inst. Marine Science, Port Aransas.

Publ. in Oceanography, Univ. of Washinglon, Seattle.

Publ. in Oceanography, Suppt. Series, Univ. of Washinglon, Seattle.

Records of Observations, Scripps Inst. of Oceanogr, La Jolla.

Research Report, U. S. Fish and Wildlife Service, Washington.

Scripps Inst. of Oceanogr., La Jolla. (Contributions).

Sears Foundation Jour: of Marine Research, New Haven.

Special Publ., Univ. of Miami Mar. Laboratory, Coral Gables.

Trans. Kentucky Acad. Sci., Lexington.

Univ. of Miami Marine Laboratory, Coral Gables. (Contributions)

Woods Hole Oceanographic Institution, Woods Hole. (Collected Reprints)

\section{PUBHICATIONS}

The outcome of researches made at the Laboratory has been published in the own journal "Publications of the Selo Marine Biological Laboratory" (commenced in 1949) and other periodicals at home or abroad. Several of them are being selected and sent regularly to the marine laboratories, institutions, museums, departments, etc. in exchange, under the subtitle of "Contributions from the Seio Marine Biological Laboratory", formed of two separate serjes, of articles in foreign and Japanese langtuages (Vide infra). 


\section{EXPLANATION OF PLATES II-V}

\section{Plate II}

Fig. 1. Plan of ground and buildings of the Laboratory. 1/2240. A-C, Official residences. D, Dormitory. E, Special research laboratory. F, Research laboratory. G, Students' laboratory. H, Museum. I, Aquarium and Specimens gallery. J, Summer house, used as dormitory. K, Meteorological observatory. L, Fresh-water pool. M, Sea-water pool for sea-turtles. N, Sea-water reservoir. O, Bansyoyama botanical garden.

\section{Pi.ATE III}

Fig. 2. Aerial view of Tanabe Bay from the south.

Fig. 3. General view of Kanayama Bay and Seto Peninsula, showing the site of the Laboratory (S.M.B.L.).

\section{Plate IV}

Fig. 4. Research laboratory.

Fig. 5. Special research laboratory.

\section{Plate V}

Fig. 6. Students' laboratory.

Fig. 7. Aquarium. 
Publ. Seto Mar. Biol. Lab., II, 2 (1952)

FLATE II

Fig. 1

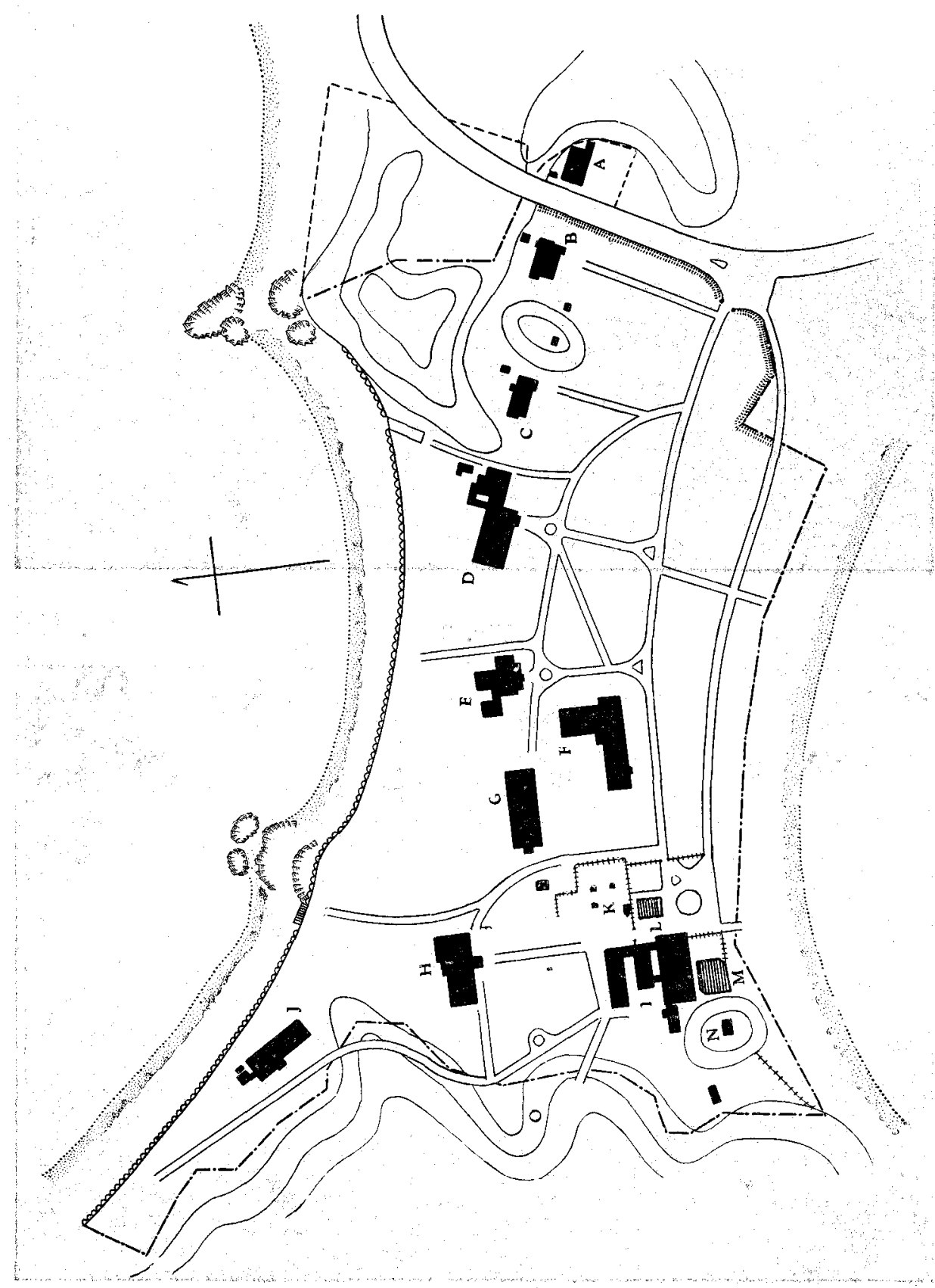


Publ. Seto Mar. Biol. Lab., II, 2 (1952)

Fig. 2

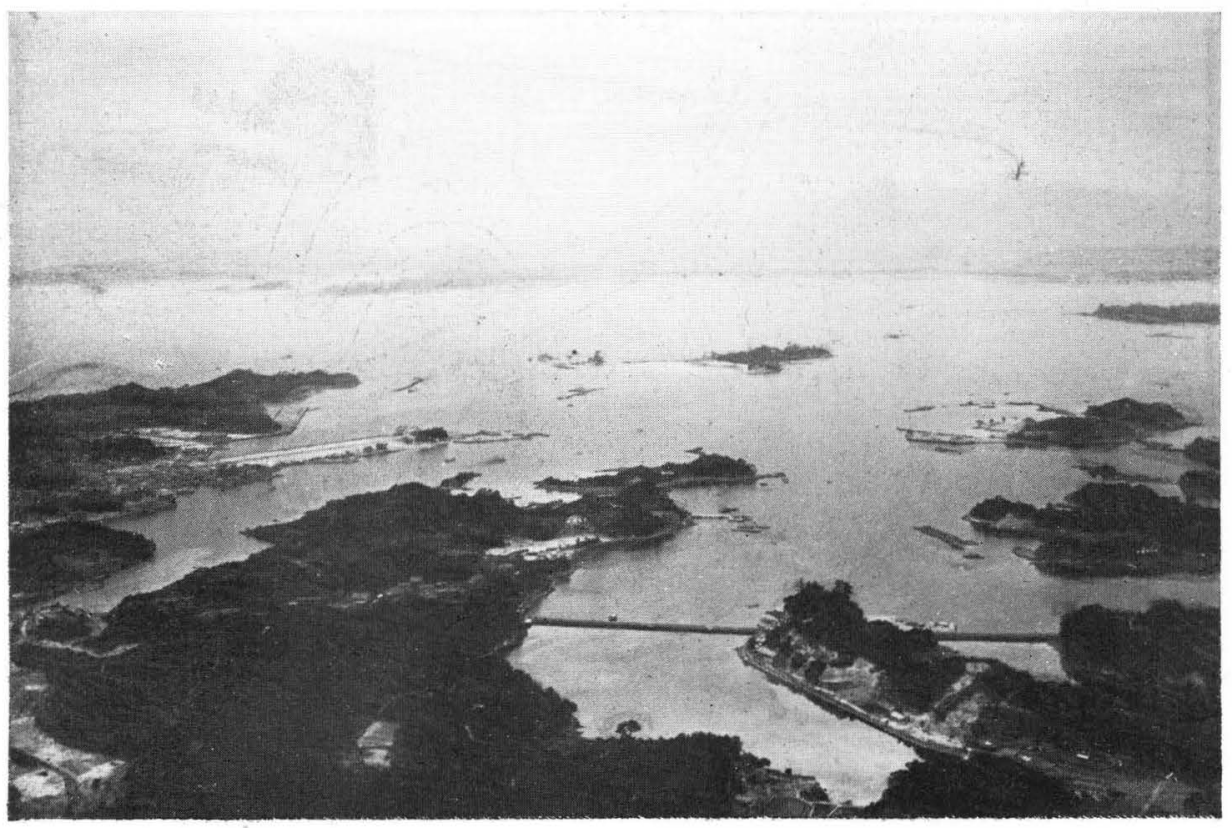

Fig. 3

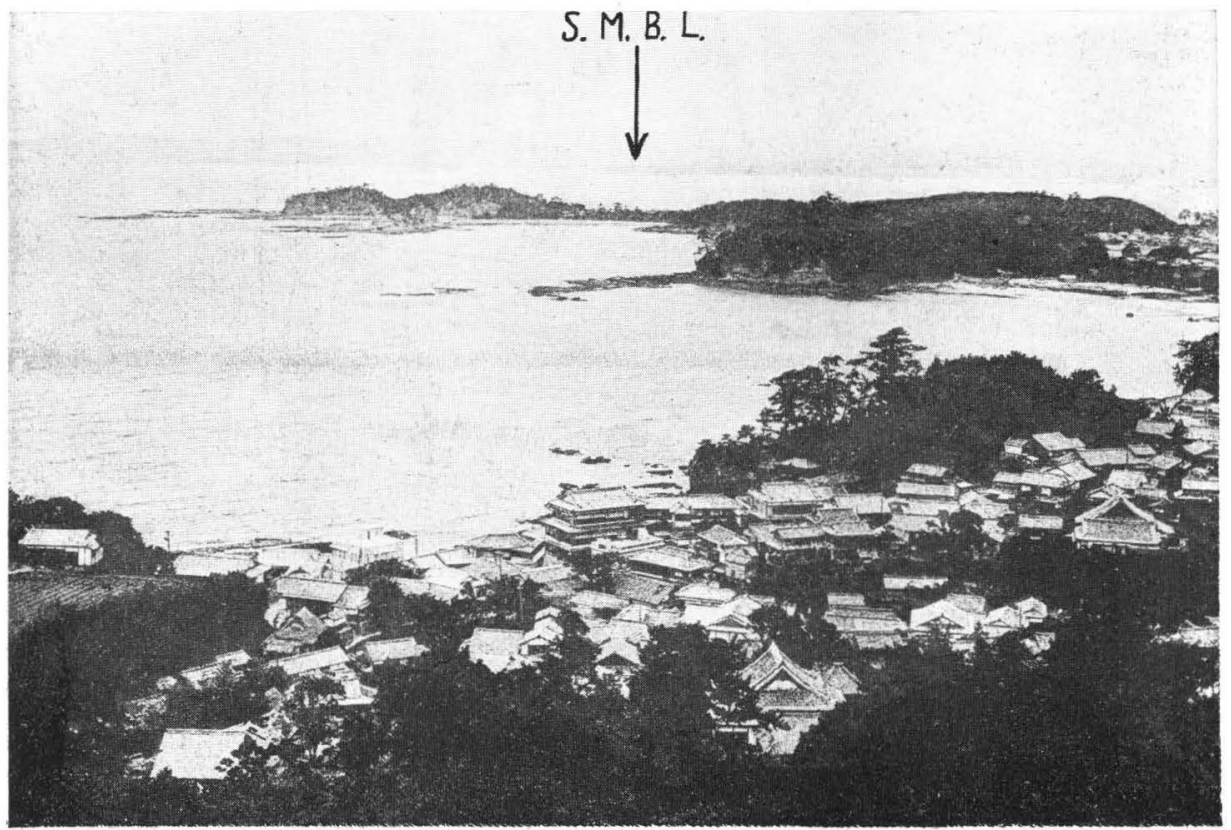

D. Miyadi \& H. Utinoni: The Seto Marine Biological Laboratory. 
Fig. 4

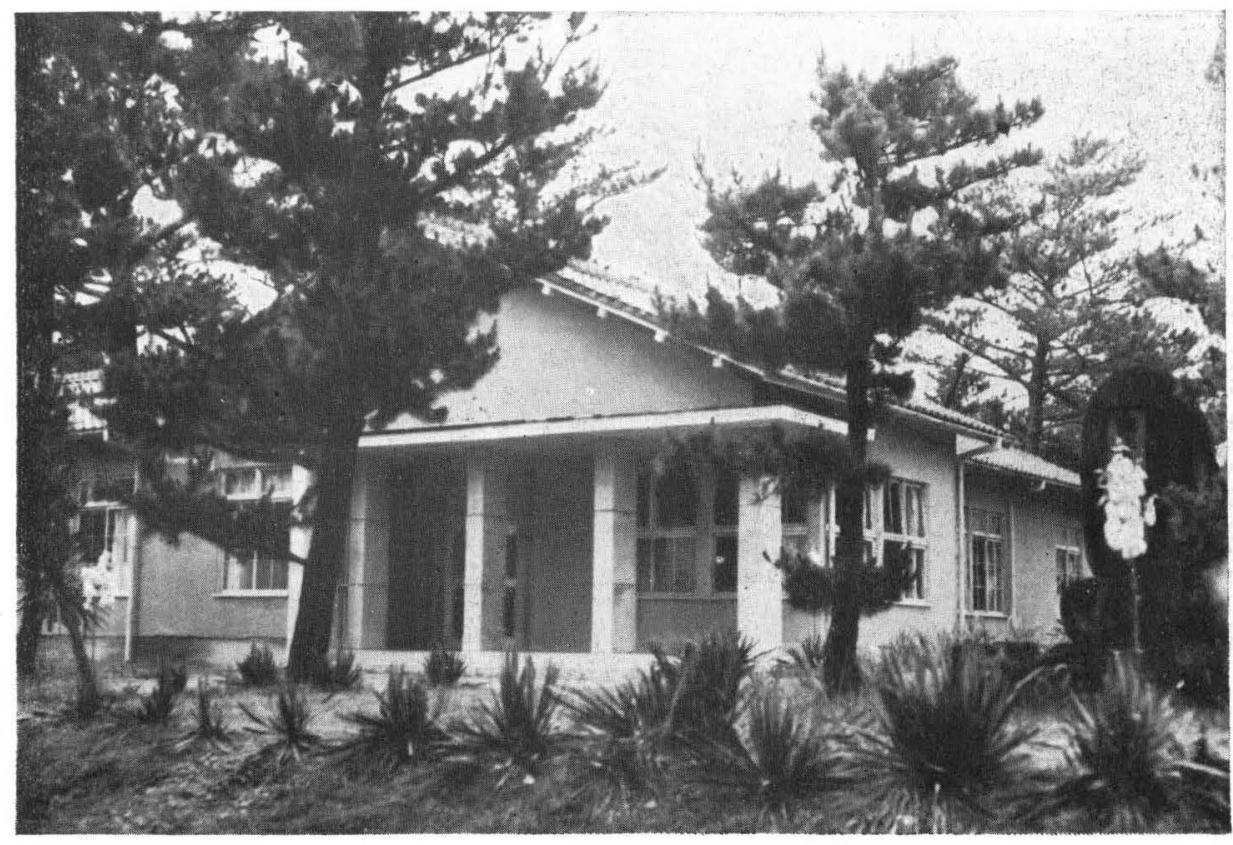

Fig. 5

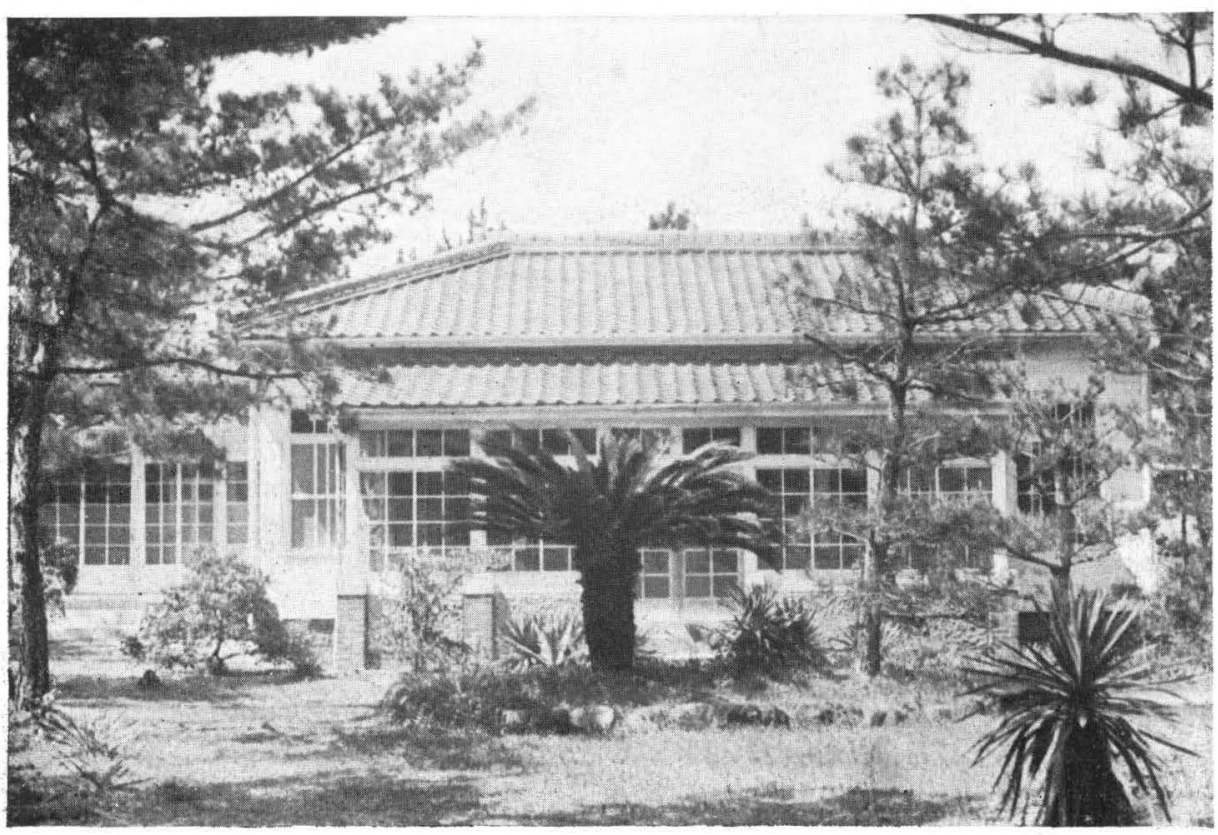

D. Miyadi \& H. Utinomi : The Seto Marine Biological Laboratory. 
Publ. Seto Mar. Biol. Lab., II, 2 (1952).

PLATE V

Fig. 6

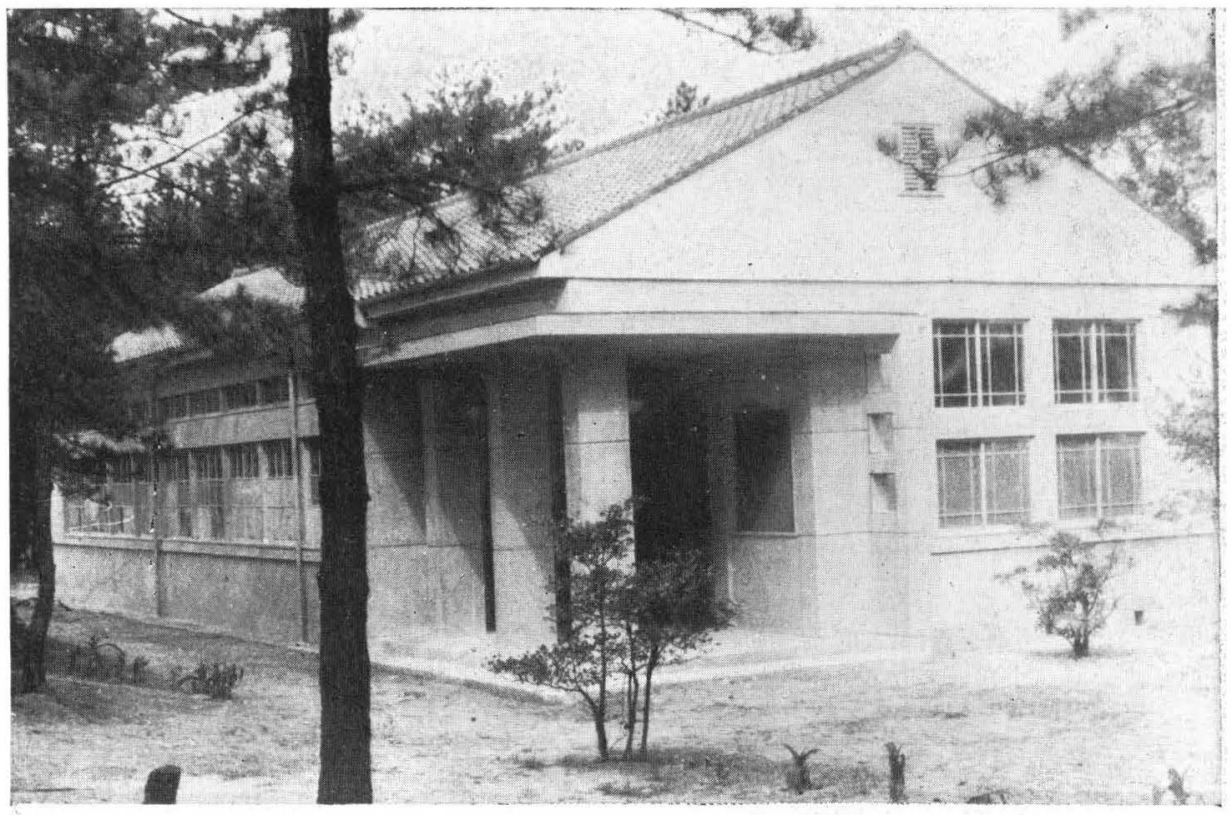

Fig. 7

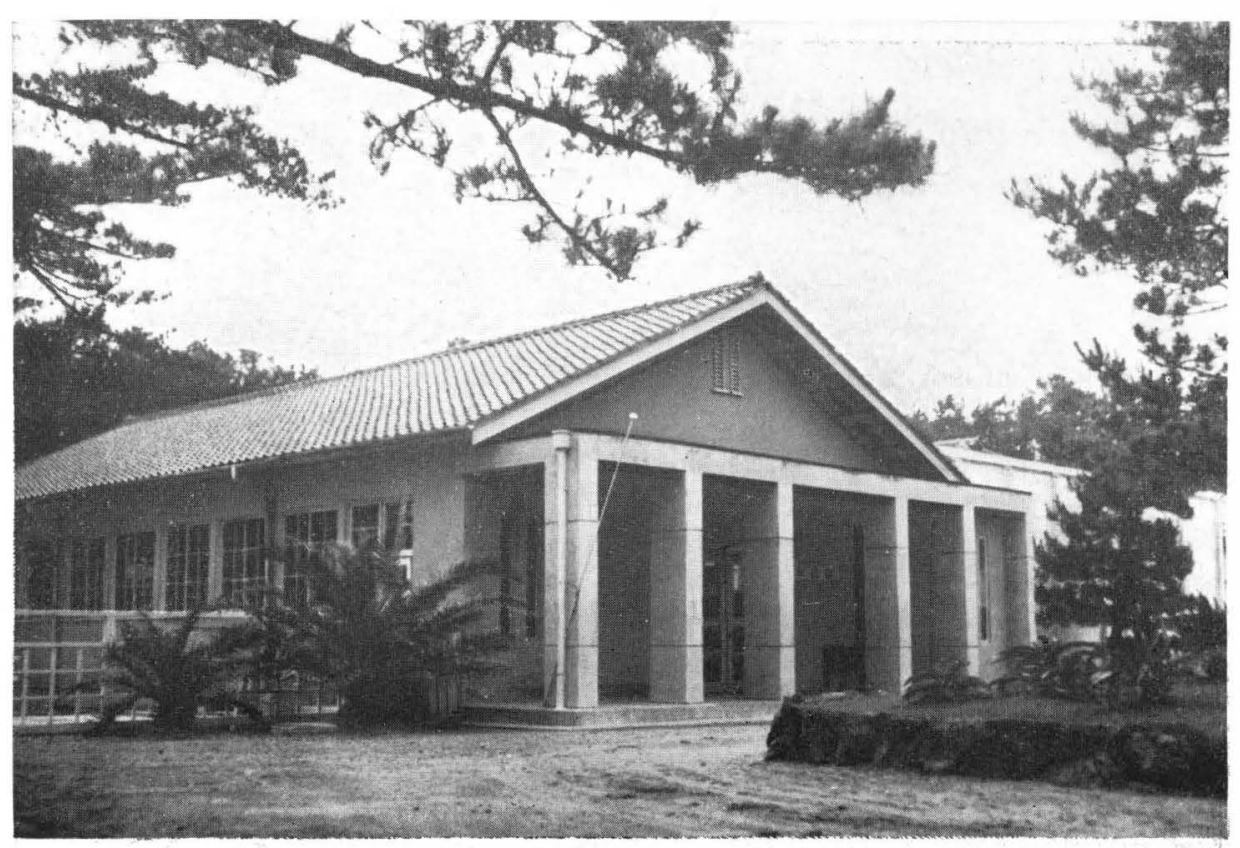

D. Miyadi \& H. Utinomi : The Seto Marine Biological Laboratory. 